\title{
Anaerobic Sediments Decrease the Leaching of Trace Metals to Groundwater
}

\author{
Amale Mcheik, 2, *, Mohamad Fakih², Hiba Noureddine², Hussein Trabulsi ${ }^{3}$, Joumana Toufaily ${ }^{2}$, \\ Taysir Hamieh $^{2}$, Evelyne Garnier-Zarli ${ }^{1}$, Noureddine Bousserrhine ${ }^{1}$ \\ ${ }^{1}$ Laboratory of Biogeochemistry and Ecology of continental regions (IBIOS - BIOEMCO), Department of Biology and Environmental \\ Sciences, Paris-Est University, Creteil, France \\ ${ }^{2}$ Laboratory of Materials, Catalysis, Environment and Analytical Methods (MCEMA), Department of Chemistry, Lebanese University, Beirut, \\ Lebanon \\ ${ }^{3}$ Faculty of Economic Sciences and Business Administration, Lebanese University, Beirut, Lebanon
}

\section{Email address:}

Amale.am@hotmail.com (A. Mcheik), fakih.mohamad@gmail.com (M. Fakih), hibanoureddine@yahoo.fr (H. Noureddine), husseintrabulsi@yahoo.fr (H. Trabulsi),joumana.toufaily@ul.edu.lb (J. Toufaily), tayssir.hamieh@ul.edu.lb (H. Taysir), garnier@u-pec.fr (E. Garnier-Zarli), bousserrhine@u-pec.fr (N. Bousserrhine)

\section{To cite this article:}

Amale Mcheik, Mohamad Fakih, Hiba Noureddine, Hussein Trabulsi, Joumana Toufaily, Taysir Hamieh, Evelyne Garnier-Zarli, Noureddine Bousserrhine. Anaerobic Sediments Decrease the Leaching of Trace Metals to Groundwater. International Journal of Environmental Monitoring and Analysis. Vol. 3, No. 3, 2015, pp. 180-190. doi: 10.11648/j.ijema.20150303.20

\begin{abstract}
The increased deterioration of water resources in Lebanon from progressive urbanization, agricultural activities and development of industries is, according to the natural authorities, a major critical problem by the year 2010. At our study site, at Al-Ghadir River, aqueous solutions containing heavy metals are extensively released from many industries directly to the river. Sediments and soil, at these sites became contaminated with these elements and their potential mobility is of particular concern since downward leaching of the heavy metals may result in the contamination of the groundwater. The objective of the present work was to investigate the bioleaching of heavy metals from the sediments of Al-Ghadir River to underground water using ex-situ column experiments. In order to conciliate the field conditions and the laboratory constraints, we have chosen to experiment the heavy metal leaching from long-term contaminated and non-destructured sediments. Sediments were incubated under anaerobic conditions and enriched with nutrients to stimulate microbial metabolism. The evolution of carbon metabolism and metals leached from the incubated sediment columns were followed over time and the effect of leaching on the distribution of metals as a function of depth was also studied. Results obtained showed that after a phase of mobilization of the heavy metals and which was enhanced by the bacterial activity, the study of the distribution profile of the heavy metals showed that they were highly readsorbed at the surface of the sediment column and their readsorption was found to decrease with depth.
\end{abstract}

Keywords: Heavy Metals, Bioleaching, Readsorption, Contaminated Sediment, Sediment Columns

\section{Introduction}

Lebanon depends primarily on groundwater that is deteriorating rapidly in quality through possible saline intrusions along its populous coast and pollution from many sources including progressive urbanization, agricultural and industrial activities ([1], [2], [3] and [4]).

These sources are the major contributors to the contamination of the soil and the sediments of Al-Ghadir River with heavy metals hence posing a long-term risk to the groundwater quality in the region. Depending on the environmental conditions, sediments and soils act as a sink for heavy metals, although they may act as a potential site of metal remobilization. The total content of heavy metals at these polluted sites cannot be considered an index for the estimation of the potential risk to other environmental reservoirs because this depends on the soluble fraction of each of the elements.

Historically, as an approximation of potential risk, several extraction procedures have been employed to estimate the mobile, labile or bioavailable pools of heavy metals in soil. The most important methods include: (i) batch extraction and 
(ii) column leaching experiments.

The sorption capacity parameter obtained from a batch experiment is useful in providing information about effectiveness of metal-biosorbent system. However, the data obtained under batch conditions are generally not applicable to most treatment system (such as column operations) where contact time is not sufficiently long for the attainment of equilibrium [5]. Hence, there is a need to perform equilibrium studies using columns which are used to provide information about heavy metal release and transport in soil, and are also useful for testing possible soil remediation or stabilization treatments, to assess heavy metal binding and adsorption kinetics, or to study processes such as colloidfacilitated metal transport at the laboratory scale ([6], [7], [8], [9]).

A series of physico-chemical and biological processes are involved in the vertical leaching or mass flow of metals in the soil ([10], [11], and [12]). In turn, these depend on the chemical characteristics of each metal and on the soil parameters, such as $\mathrm{pH}$, the carbonate content, free iron and aluminum oxide contents, the nature and the content of the clay and organic matter fractions [13] and the microbiological activity ([12], [14], [15] and [16]).

Many studies have been carried out aimed at predicting the mobility of results from contaminated soils based on the forms extractable with $\mathrm{CH}_{3}-\mathrm{COOH}$ and with $\mathrm{CaCl}_{2}$ and on the distribution coefficients, $\mathrm{Kd}$ of a given metal in a given soil or based on the forms extractable with $\mathrm{CaCl}_{2}$ and with EDTA but only few studies have been done, which are more realistic talking about the mobility or leaching of heavy metals in the affected soils, such as investigations that involve the leaching with water or with a media of soil columns that simulate field leaching conditions with river water [17]. Thus, the objective of this study was, on the one hand, to determine the retention and the relative leaching of $\mathrm{Fe}, \mathrm{Mn}, \mathrm{Cd}, \mathrm{Zn}, \mathrm{Cu}, \mathrm{Pb}$ and $\mathrm{Cr}$ from the contaminated sediments and soils using packed sediment columns and, on the other hand, to determine the efficacy of the sediment themselves at attenuating metal mobility as a function of their physicochemical and biological properties. The mobility of the elements was also studied in the affected sediment columns with an aim to determining the distribution profile of the metals by simulating their leaching in the field by rainwater. These studies can provide data at this time in order to take decisions concerning the need for the immobilization of the metals and for the selection of remediation technologies of the soils.

\section{Materials and Methods}

\subsection{Study Area and Sampling Methodology}

The first hundred centimeters of sediments were collected from one site of Al-Ghadir River in November 2012 with an auger. This site is located at the end of the river just before its water passes in tunnels near the airport and before its release to the Mediterranean Sea. It was chosen because it was shown that it is the most polluted site chemically and biologically all along the river. Once collected, sediment samples were transferred into a $10 \mathrm{~L}$ plastic bottle previously soaked in $10 \%$ ultrapure HNO3 for $48 \mathrm{~h}$ to avoid any metallic contamination then rinsed with milliQ water for $24 \mathrm{~h}$.

\subsection{Experimental Set-Up}

The relative and the effect of leaching on the distribution of the elements at depth were studied under anaerobic conditions on three lab scale columns $(10 \mathrm{~cm}$ inner diameter and $25 \mathrm{~cm}$ height) (Figure 1) using distilled water and 2 different media, Bromfield (amended by [18]) and a synthetic media.

Column flushed with distilled water was used only as a control for comparison purposes. Each of the other columns was operated to simulate the leaching due to the applications of the media (synthetic and Bromfield) continuously to the sediment all along the experiment. These culture media were used to simulate the bacterial growth, accelerate the evolution of sediments and study the impact of the microbial activity on the release of metals. The 2 different media (synthetic and Bromfield) were tested in separate columns. The chemical composition and the ionic strength of the synthetic and Bromfield media were chosen to be comparable to the pore water composition in the river (Synthetic media: $\mathrm{KH}_{2} \mathrm{PO}_{4}, 0.5 \mathrm{~g} / \mathrm{l} ; \mathrm{MgSO}_{4} .7 \mathrm{H}_{2} \mathrm{O}, 0.5 \mathrm{~g} / \mathrm{l} ;\left(\mathrm{NH}_{4}\right)_{2} \mathrm{SO}_{4}, 1 \mathrm{~g} / \mathrm{l}$; Yeast extract, $0.15 \mathrm{~g} / \mathrm{l}$ and Bromfield media: $\mathrm{KH}_{2} \mathrm{PO}_{4}, 0.5 \mathrm{~g} / \mathrm{l}$; $\mathrm{MgSO}_{4} \cdot 7 \mathrm{H}_{2} \mathrm{O}, 0.5 \mathrm{~g} / \mathrm{l} ;\left(\mathrm{NH}_{4}\right)_{2} \mathrm{SO}_{4}, 1 \mathrm{~g} / \mathrm{l}$; Yeast extract, $0.15 \mathrm{~g} / \mathrm{l}$; glucose, $10 \mathrm{~g} / \mathrm{l})$. The $\mathrm{pH}$ of the media used in the different columns was 8 , this being similar to that of the river water (pH 8.20).

The column consists of a closed system in which the incubation started with a known volume of substrate that the autochthonous microorganisms present in the studied sediments will continuously utilise it for their growth. Each column consists of 2 transparent reservoirs each of $25 \mathrm{~cm}$ height and $10 \mathrm{~cm}$ inner diameter and connected together by flexible tubes thus allowing a continuous circulation of the effluent along the system. The different effluents were sterilized before use by autoclave. Incubation started when $800 \mathrm{ml}$ of the sterilized effluents were introduced into the column containing $500 \mathrm{~g}$ of sediments.

Anaerobic conditions were created by degasing the system with $\mathrm{N} 2$ and incubations were conducted for 2 months at $28 \pm 2^{\circ} \mathrm{C}$, at a flow rate of $0.12 \mathrm{ml} / \mathrm{s}$ and without shaking to avoid resuspension of sediments and consequently to only consider diffusion of metals during the incubation and simulate diffusion of metals in calm and anaerobic areas. Incubations of sediments were realized in duplicates and all manipulations were done in a manner to limit the microbial contamination of the sediments and the reservoirs. These effluents were in continuous circulation between the 2 reservoirs of the column by 2 peristaltic pumps which control the flow at $0.12 \mathrm{ml} / \mathrm{s}$ to maintain system under non-saturated conditions, the first placed at the end of the 1rst reservoir and the 2 nd at the end of the 2 nd reservoir. The effluent when entering the soil reservoir crosses a layer of $1 \mathrm{~cm}$ of glass 
beads where their role was to allow the arrival of the effluent on the whole surface of the sediments and avoid the formation of preferential paths.

Under the sediments, a layer of sand with a high permeability and of $1 \mathrm{~cm}$ thickness was used to allow the cohesion of the base of the column thus permitting the circulation of the leachate. Under the layer of the sand, a plastic grid was used to support the sediments and the sand and prevents their passage and blockage of the pumps hence allowing the continuous circulation of the leachate. Below the grid, another layer of $1 \mathrm{~cm}$ of glass beads was used to allow for easier recovery of the leachate and its circulation through the pump till reaching the solution reservoir which contains only the effluent and which was equipped with a rubber cover to allow the sampling of a volume of the effluent by a sterile syringe with a continuous preservation of the anaerobic conditions of the system (Figure 1). Before use, the different parts of the column, the pumps, the glass beads, the containers used and the sand were soaked in $2 \%(\mathrm{v}: \mathrm{v})$ nitric acid for $24 \mathrm{~h}$ to eliminate traces of soluble substances and then in ultrapure water for $48 \mathrm{~h}$ then sterilized by autoclaving and the sand was dried after sterilization.

Samples of $10 \mathrm{ml}$ were taken at different time intervals to achieve chemical and biological analysis of the media. The samples were collected in sterile tubes where the $\mathrm{pH}$ and the redox potential $(\mathrm{Eh})$ were measured directly in the leachate. The samples were then centrifuged and filtered through 0.45 $\mu \mathrm{m}$ cellulose acetate filter with $4 \mathrm{ml}$ were kept at $4{ }^{\circ} \mathrm{C}$ for organic analysis and $4 \mathrm{ml}$ were acidified by the addition of $2 \%$ nitric acid and stored at $4{ }^{\circ} \mathrm{C}$ for mineral analysis.

At the end of the experiment, the concentration of the total metals was detected at the different depths of the sediments in the columns. Bacterial counting was also detected at the top and the bottom of the sediments and finally a study of the bacterial diversity was done in the sediments of the different columns to be compared with the results obtained before incubation.

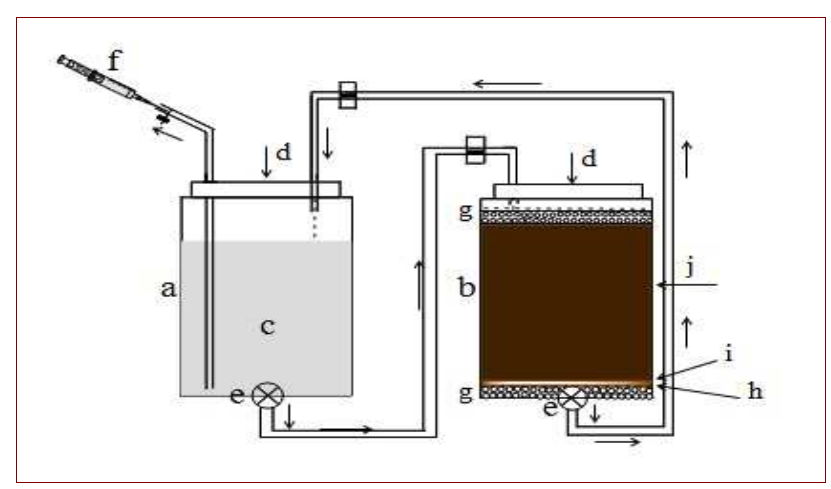

Figure 1. Experimental column set-up. a) Solution reservoir, b) sediment reservoir, c) media (effluent), d) $\mathrm{N}_{2}$, e) peristaltic pump, f) sampling syringe, g) glass beads, h) plastic grid, i) layer of sand, j) sediments.

\subsection{Study of the Microbial Metabolism and Bacterial Diversity}

\subsubsection{Study of the Microbial Metabolism}

During the anaerobic flooding, about $10 \mathrm{~mL}$ of soil solution were sampled at each sampling time. The samples were filtered through a $0.45 \mu \mathrm{m}$ (pore diameter) cellulose acetate filter. They were divided into several aliquots for analysis of glucose, organic acids and total metals. $\mathrm{pH}$ and Eh were measured in $1 \mathrm{ml}$ of non-filtered solution using a $\mathrm{pH}$ meter (PHS-W; Microprocessor $\mathrm{pH} / \mathrm{mV} /$ temperature Meter).

Glucose was measured enzymatically in $1 \mathrm{ml}$ of the culture medium using a commercial kit (kit D-Glucose/, Roche). Total organic (TOC) and organic carbon (OC) were measured by an elemental analyzer (TOC SKALAR Formacs ${ }^{\mathrm{HT}}$ ). Butyrate and acetate which were the main organic acids produced during glucose fermentation [19] were analyzed in $1 \mathrm{ml}$ of medium solution by HPLC according to [20]. The separation of organic acids was realized by HPLC with a reversed phase column (Thermo ODS hypersil $5 \mu \mathrm{m}$, $4.6 \mathrm{~m} * 250 \mathrm{~mm})$ and a gradient of $\mathrm{KH}_{2} \mathrm{PO}_{4}(20 \mathrm{mM})$ and acetonitrile.

\subsubsection{Study of the Microbial Diversity: DNA Extraction, PCR Amplification and DGGE}

DNA extraction was carried out on duplicate of $0.25 \mathrm{~g}$ of wet sediment samples before their incubation and of the different column sediment samples after their incubation using the PowerSoilTM DNA extraction kit (MoBio laboratories Inc., Ozyme, France) according to the manufacturer's instructions.

16S rRNA amplification was carried out using primers 518r and 338f (Table 1). The PCR was realized on $1 \mu \mathrm{l}$ of DNA added to $14 \mu \mathrm{l}$ of the mixture containing $0.375 \mu \mathrm{l}$ of each of the primer set, $7.5 \mu$ l of the Taq polymerase (Master Mix) and $5.75 \mu \mathrm{l}$ of sterilized ultrapure water. PCR amplification was performed by using a PTC-200 Peltier-effect Thermal Cycler (BioRad). Amplification conditions were as follows: $94^{\circ} \mathrm{C}$ for $3 \mathrm{~min}$ (initial denaturation), followed by hybridation at $60^{\circ} \mathrm{C}$ for $1 \mathrm{~min}$, elongation for $3 \mathrm{~min}$ at $72^{\circ} \mathrm{C}$ with the final extension step at $72^{\circ} \mathrm{C}$ for $15 \mathrm{~min}$. Negative controls (without DNA) were run in all amplification.

DGGE was performed with $9 \%$ (wt/vol) acrylamide gel containing a linear chemical gradient ranging from 30 to $60 \%$ denaturant, and run for $15 \mathrm{~min}$ at $60^{\circ} \mathrm{C}$ and $150 \mathrm{~V}$ and then for $6 \mathrm{~h}$ at $60^{\circ} \mathrm{C}$ and $20 \mathrm{~V}$ using the BioRad D-CodeTM system (BioRad laboratories, Inc. Ozyme, France). After electrophoresis, the gel was soaked in ethidium bromide nucleic acid gel stain solution for $15 \mathrm{~min}$ and then rinsed with milliQ water for $10 \mathrm{~min}$ and then photographed under ultraviolet with gel reader Geldoc 2000 (BioRad, Marnes La Coquette, France) and analyzed with the logiciel Quantity one (BioRad, Marnes La Coquette, France).

Table 1. Characteristics of the fragments used during the genetic characterization of the total microbial community

\begin{tabular}{|c|c|c|c|c|}
\hline Fragments & Sequences $5^{\prime} \rightarrow 3$, & Position & Region of 16S rRNA & Reference \\
\hline $338 \mathrm{f}(\mathrm{F})+$ & ACTCCTACGGAGGCAGCAGATTACCGCGGCTGCTG & $338-355$ & V3 & Muyzer et al., 1993 [21] \\
\hline $518 \mathrm{r}(\mathrm{R})$ & & $518-534$ & & \\
\hline
\end{tabular}




\subsection{Metals in Solution and in Sediments}

Sediments were dried at room temperature and sieved with retaining the sediment size fraction of $<250 \mu \mathrm{m}$. Total metals in sediments were quantified before their incubation as well as at the different depths in the sediments of the different columns after their incubation by flame atomic absorption spectrometry (Ray Leigh Model WFX-210 AAS) using airacetylene flame. 7 major elements were analyzed: Fe, Mn, $\mathrm{Cu}, \mathrm{Cd}, \mathrm{Zn}, \mathrm{Pb}$ and $\mathrm{Cr}$ and quantification of metals was based upon calibration curves of standard solutions of respective metals. The precision of the metal analysis was controlled by including duplicate samples in analytical batches.

\section{Results and Discussion}

\subsection{Microbial Metabolism}

\subsubsection{Fermentation Process}

Results presented in Figure 2 showed that in the column which was provided with Bromfield media, the rate of carbon mineralization was high during the first week and was followed by a plateau indicating the consumption of the carbon source. No latency period was observed at the beginning of the experiment meaning a good physiological state of microorganisms and a good adaptation to the experimental conditions. These results have shown that the addition of glucose as a source of carbon which is easily biodegradable has considerably accelerated the processes of bacterial growth. After the 1rst week of incubation, glucose was totally degraded and 2 organic acids, acetate and butyrate, were detected. The maximum of acetate was observed during the 5 th day of incubation $(250 \mathrm{mg} / \mathrm{l})$ and was followed by a plateau and decreased at the end of the incubation while butyrate increased during the first 5 days to attain a value of $575 \mathrm{mg} / \mathrm{l}$ and was followed by a plateau and decreased slightly at the end of the incubation. The production of such organic acids indicates that fermentation metabolism occurred [22]. Furthermore, [23] also demonstrated that in soils enriched with glucose in anaerobic conditions, the microbial metabolism of glucose led to the production of acetate. Acetate decreased between the days 5 and 10 of incubation and then reached a plateau and this is may be due to the bacterial consumption of this organic acid after being produced by them and then the disappearance of this group of bacteria or their adaptation another metabolic pathway after this period hence giving the shape of plateau and the decrease of this acid at the end of incubation may be due to its bacterial consumption as the only source of energy left after this period. Butyrate increased during the first five days when glucose was consumed and then reached a plateau where the bacteria may have adapted to these conditions and then slightly decreased at the end of the incubation, this decrease may be due to the consumption of this source of carbon needed by the bacteria during this period. This column turned black in color also after 10 days of incubation indicating a strong reduction of sulphate as showed by [24].
Most of the organic carbon introduced as glucose was transformed into organic acids and mineralized carbon and the organic carbon not determined can be due to the production of other metabolites such as alcohols, amino acids and other polysaccharides not analyzed and to the increase of the biomass.
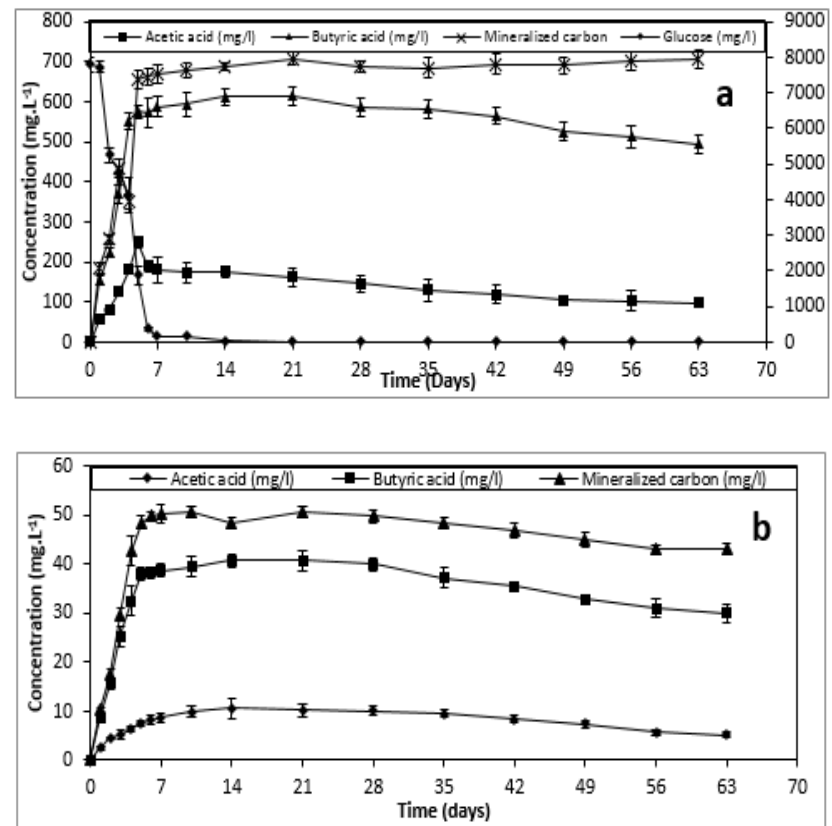

Figure 2. Evolution of organic acids and mineralized carbon during incubation of the sediments with Bromfield media (a) or synthetic media (b).

In the column which was supplied with the synthetic media without glucose (Figure 2b), the rate of carbon mineralization was lower than that of Bromfield media and was induced by the bacterial degradation of the endogenous organic matter present in the sediments and which was used as a substrate for these bacteria [19].

In this column, organic acids acetate and butyrate were detected but in concentrations smaller than those obtained in the case of Bromfield media and which reached about 7.5 $\mathrm{mg} / \mathrm{l}$ and $38.1 \mathrm{mg} / \mathrm{l}$, respectively after 5 days of incubation and then decreased to 5.2 and $30 \mathrm{mg} / \mathrm{l}$, respectively at the end of the incubation and this may be due to a partial consumption by the autochthonous microorganisms [25].

The column which was supplied with distilled water has shown a very low carbon mineralization rate which was mainly produced from the biodegradation of the endogenous organic matter in the sediments and this is due to the complete lack of any other nutritive material for the development of the autochthonous microorganisms. In this column, the production of the organic acids was not observed.

\subsubsection{Acidification of the Medium}

The column which was supplied with glucose has shown a strong acidification of the media after 5 days of incubation with a decrease of the $\mathrm{pH}$ from 8.00 to 6.7 during the first 5 days of incubation, then after the 1rst week (the day 7), the 
pH slightly decreased until 6.1 and remained constant till the end of the incubation. This acidification of the medium is due to the fermentation of glucose and to the production of organic acids during the development of the bacteria under anaerobic conditions. In this column, Eh decreased from 175 $\mathrm{mV}$ to $-24 \mathrm{mV}$ during the first 3 days and after 1 week, Eh reached $-243 \mathrm{mV}$ and reached -185 at the end of the incubation.

The sharp decrease in the $\mathrm{pH}$ was not observed in the other columns which were supplied with the synthetic media and with the distilled water where it was shown that the column which was supplied with the synthetic media, the $\mathrm{pH}$ decreased from 8 to 7.1 during the first 10 days and then increased at the end of the $2^{\text {nd }}$ week to 7.2 and remained constant till the end of the incubation, this decrease in the $\mathrm{pH}$ is due to the production of a small concentration of organic acids and their consumption by the bacteria and which may explain the increase of the $\mathrm{pH}$ during the $2 \mathrm{nd}$ week. In this column, Eh decreased also from 192 to $14 \mathrm{mV}$ in the first 3 days and reached $-127 \mathrm{mV}$ after one week and then raised -76 $\mathrm{mV}$ at the end of the incubation. The column which was supplied with distilled water, it was shown that the $\mathrm{pH}$ slightly decrease from 8.0 to 7.7 and then increased to 7.9 and then remained constant till the end of the incubation, this slight increase may be due to the absorption of protons from the soil components ([18] and [26]), in this column a sharp decrease in the Eh was shown at the beginning of the experiment.

\subsection{Metals in the Sediments and the Leachates and Their Relationship with the Microbial Metabolism}

\subsubsection{Total Metals in Sediments Before Their Incubation}

Table 2 shows the total contents of $\mathrm{Cd}, \mathrm{Zn}, \mathrm{Pb}, \mathrm{Cu}, \mathrm{Fe}, \mathrm{Mn}$ and $\mathrm{Cr}$ in the sediments taken from the studied site of AlGhadir River (site E) before their incubation. The content of most of these metals is high and based on values considered to be critical by different investigators. Such high previous pollution is not surprising because it is from an area of influence of industries.

Table 2. Characteristics of the river sediments before incubation.

\begin{tabular}{llll}
\hline Parameter & \multicolumn{3}{c}{$\begin{array}{l}\text { Parameter ( } \boldsymbol{\mu g . g - 1} \\
\text { dry sediments) }\end{array}$} \\
\hline $\mathrm{pH}$ & 8.2 & $\mathrm{Fe}$ & 13570 \\
Sand (\%) & 41.2 & $\mathrm{Mn}$ & 328 \\
Silt (\%) & 17.5 & $\mathrm{Cd}$ & 35.4 \\
Clay (\%) & 41.3 & $\mathrm{Zn}$ & 254 \\
Organic matter (\%) & 14.72 & $\mathrm{Cu}$ & 146.5 \\
CEC (meq/kg) & 35 & $\mathrm{~Pb}$ & 125 \\
Carbonate content (\%) & 8.78 & $\mathrm{Cr}$ & 45.6 \\
\hline
\end{tabular}

\subsubsection{Metals Leached in the Different Columns}

Figure 3 shows the leaching curves of $\mathrm{Fe}, \mathrm{Mn}, \mathrm{Cd}, \mathrm{Zn}, \mathrm{Pb}$, $\mathrm{Cr}$ and $\mathrm{Cu}$ in packed columns of sediments. In the column which was supplied with Bromfield media, high dissolution of $\mathrm{Fe}$ and $\mathrm{Mn}$ appeared after one week of incubation (Figure 3). Same trends were observed for the dissolution of Fe and $\mathrm{Mn}$ in the column supplied with the synthetic media but dissolved amounts were lower than in the case of Bromfield media and the column which was supplied with distilled water showed traces of leachable metals in the solution. The dissolution of $\mathrm{Fe}$ and $\mathrm{Mn}$ was maximum during the first days of the experiments and synchronous with the higher decrease of $\mathrm{pH}$. Several processes may be involved in the relationship between lowering of $\mathrm{pH}$ and metal release, which has been widely demonstrated for various substrates ([27], [28], [29], [30], [31], [32], [33] and [34]).

However, as shown in the column supplied with the synthetic media, no strict correlation was observed between $\mathrm{pH}$ and $\mathrm{Fe}$ and $\mathrm{Mn}$ release since after the $\mathrm{pH}$ decrease during the first week, $\mathrm{pH}$ increase slowly while metals were still leached and a reverse relationship (dissolved metals increase with an increasing $\mathrm{pH}$ ) was found for the final part of the experiment. Same trends as our results are observed in a previous study, in which an increase of the leached metals were observed in soils with a decrease of the $\mathrm{pH}$ but both parameters were not obviously correlated [35]. In their study, the only relationship with $\mathrm{R} 2$ values above 0.2 was found for $\mathrm{Cu}$ and $\mathrm{Cr}$ concentration versus $\mathrm{pH}$ in addition high correlation was found for $\mathrm{Cu}$ and $\mathrm{Cr}$ concentration versus $\mathrm{pH}$ in addition high correlation was found between $\mathrm{C}$ mineralization and the leaching of $\mathrm{Fe}$ and $\mathrm{Mn}$, more precisely dissolved iron attained a plateau when glucose is consumed (Figure 2a, 2b) hence suggesting the presence of iron and manganese reducing bacteria. Indeed some fermentative bacteria have been shown to oxidize the organic matter by reducing iron and manganese oxides at the same time to use them as final electron acceptor [19] and the production of butyric acid is characteristic of the microorganisms Clostridium butyricum, known for its iron-reducing activity.

The leaching profile of the other metals was similar to the leaching profile of $\mathrm{Fe}$ and $\mathrm{Mn}$ in the columns supplied with Bromfield and with the synthetic media, but the leaching profile of the metals in the column supplied with distilled water was very low and nearly negligible and this is due to the complete absence of the nutrients responsible for the growth of the autochthonous bacteria and which showed an important role in their leaching of the heavy metals. In addition, the leaching profile of the metals in the different columns was shown to be high at the beginning of the incubation and decreases at the end. This decrease may be due to the aging of the contamination by the heavy metals which decrease the solubility of the heavy metals with time. In the column supplied with Bromfield media, a high rate of heavy metal leaching was observed beginning from the $3 \mathrm{rd}$ day of incubation and then decreases till it reached a plateau where the concentration of most of the measured metals remained constant till the end of the incubation. The shape of the elution curves of the different metals was very similar. Figure 3 showed the leaching curves of $\mathrm{Fe}, \mathrm{Mn}, \mathrm{Zn}, \mathrm{Cd}, \mathrm{Pb}$, $\mathrm{Cr}$ and $\mathrm{Cu}$ leached from the sediments during incubation. The leaching curves of $\mathrm{Cd}$ from the sediments (Figure 3) display an initial elution maximum and the maximum amount leached reached about $16 \%$ from the column supplied with Bromfield media and $12 \%$ for the column supplied with the 
synthetic media and based on the leaching curves obtained from the studied sediments, all the potentially leachable $\mathrm{Cd}$ of the column has passed to the leachates under the experimental conditions.

What is of great importance is that the concentration of the metals leached was important and was affected by bacterial activity in the sediments but also the characteristics of the sediments of the studied region (clay rich sediment with a high carbonate content) (Table 2) have a good capacity to immobilize the soluble fraction of the elements and they showed an important role in the control of the adsorption of the metals in the sediments ([36] and [37]). These characteristics govern the distribution of the elements in the profile of natural soils ([38], [39] and [40]).

The leaching curves of $\mathrm{Zn}$ in the sediments (Figure 3) are very similar to those of $\mathrm{Cd}$ and the percentage of $\mathrm{Zn}$ leached from the different columns is slightly lower than that of $\mathrm{Cd}$. This kind of behavior is in agreement with results showing that $\mathrm{Zn}$ is less mobile than $\mathrm{Cd}$ ([41] and [42]). Decreased mobilization of this element may be related to the high contents of organic matter and clay in this soil, as these fractions are the dominant controls of $\mathrm{Zn}$ adsorption in soils [43].

Considered to be the least mobile heavy elements in the sediment and the soil ([12], [14], [15] and [16]) $\mathrm{Pb}$ and $\mathrm{Cr}$ are almost completely immobilized in all the columns, the maximum amounts leached was in the column supplied with Bromfield media where the $\%$ of $\mathrm{Pb}$ and $\mathrm{Cr}$ leached reached about 6 and 5\%, respectively; and what is important is that the organic matter content and the free oxides and carbonates and their joint action seem to be sufficient for the element to become immobilized in all the columns [44].

$\mathrm{Cu}$ showed low mobility in the different columns, about $12 \%$ of the total of $\mathrm{Cu}$ in the columns was leached. According to the leaching curves, the amounts of $\mathrm{Cu}$ leached are higher than those of $\mathrm{Pb}$ and $\mathrm{Cr}$ which, these later, showed a similar leaching behavior in the calcareous sediments studied and were liberated with great difficulty (Figure 3). As is known $\mathrm{Cu}, \mathrm{Cr}$ and $\mathrm{Pb}$ are the least mobile heavy metals [14] and $\mathrm{Cu}$ is strongly adsorbed by all the colloidal components of the sediments such as oxides of iron and manganese, clays and organic matter and the amounts of these components in the studied sediments and soil seem to be sufficient for the immobilization of this element. According to these results, the relative leaching of the elements studied in the polluted sediments calculated from the percentages leached in the soil columns are as follows: $\mathrm{Fe}>\mathrm{Mn}>\mathrm{Cd}>\mathrm{Zn}>\mathrm{Cu}>\mathrm{Pb}>\mathrm{Cr}$. The decrease of Eh in the different columns during the leaching process indicates the installation of the solubilization process. In studies on the leaching of these metals added to packed and undistributed soil columns, [45] found that the mobility of the metals in the soils tended to follow the order of $\mathrm{Cd}>\mathrm{Zn}>\mathrm{Cu}>\mathrm{Pb}>\mathrm{Cr}$ and the lowest mobility was observed in a fine-loamy soil with a relatively high $\mathrm{pH}$.
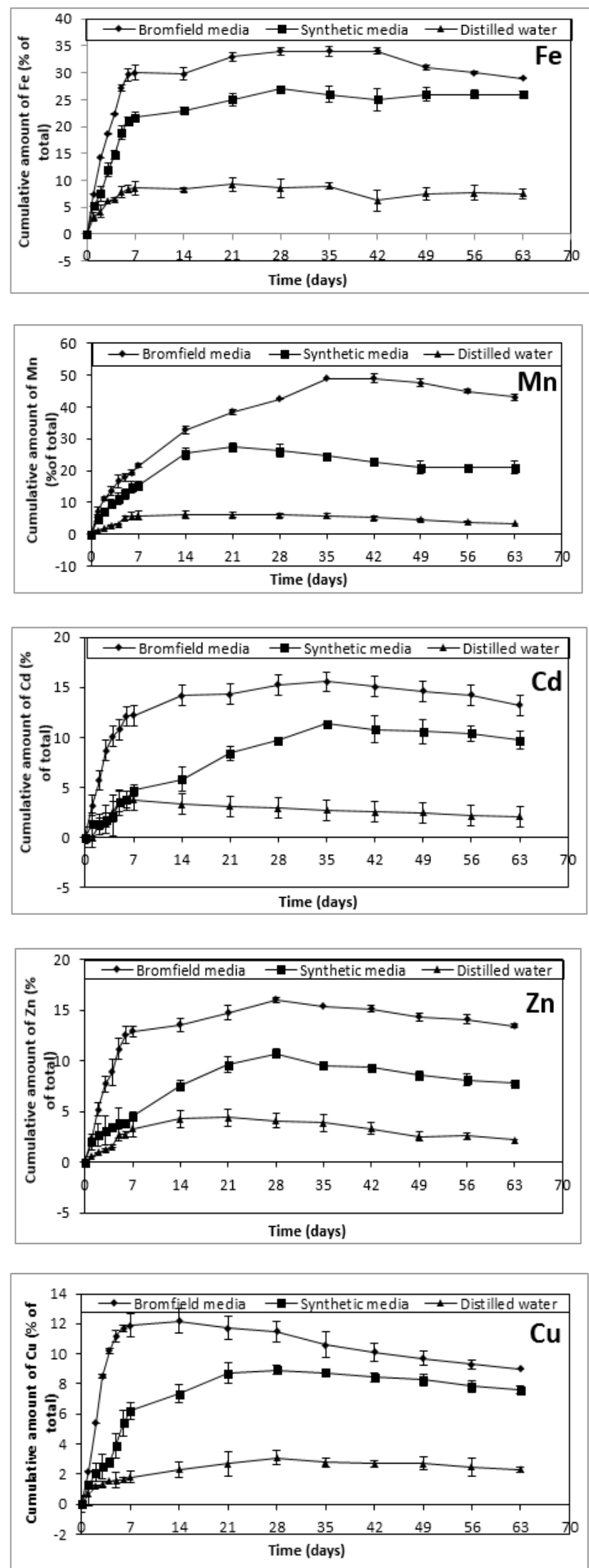

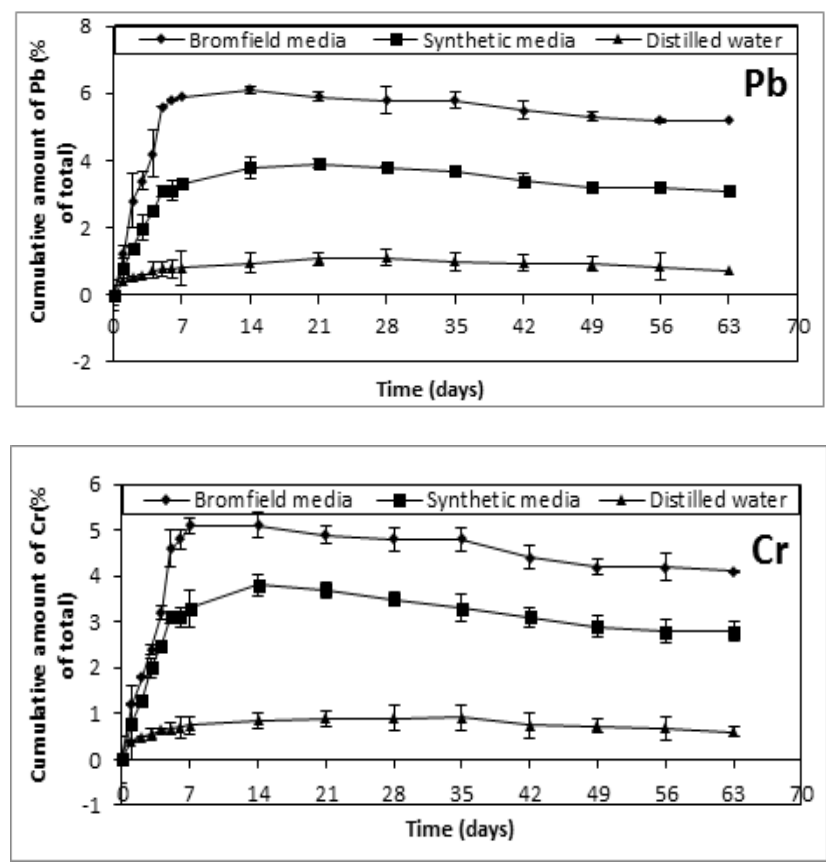

Figure 3. Cumulative curves of metal leaching in columns of sediments.

\subsubsection{Distribution Profiles of the Metals After Leaching}

Figure 4 shows the distribution profiles of $\mathrm{Fe}, \mathrm{Mn}, \mathrm{Cd}, \mathrm{Zn}$, $\mathrm{Cu} \mathrm{Pb}$ and $\mathrm{Cr}$ in the sediment columns after being leached with $800 \mathrm{ml}$ of media. In addition to the results of metal leaching which showed us that the solubilization of the studied heavy metals was homogenous in the different columns (Figure 3), the distribution profile of the studied elements in the different columns which were incubated anaerobically was shown also very similar, an accumulation in the first segments that reaches a greater or lesser depth depending on the metal and the nutritive materials but what was shown and was of great importance is that the concentration of the metals detected in the incubated sediments at the different depths at the end of the incubation, after being leached and after they have been detected in leachates, was shown high at the surface of the sediment columns (depth interval $0-10 \mathrm{~cm}$ ) and decreases with increasing depth (depth interval $10-25 \mathrm{~cm}$ ). This phenomenon can be explained by the fact that the metals after being dissolved and passed with the solution, each time they reentered with the leachate and reached the sediments, a part of these leached metals was readsorbed to the newly formed phases and which explains the decrease in the concentration of the metals in the leachate at the end of incubation.

In the column, which was supplied with Bromfield media, the accumulation of $\mathrm{Fe}, \mathrm{Mn}, \mathrm{Cd}$ and $\mathrm{Zn}$ occurred down to 14 $\mathrm{cm}$ and that of $\mathrm{Cu}, \mathrm{Pb}$ and $\mathrm{Cr}$ down to $10 \mathrm{~cm}$, while the column which was supplied with the synthetic media, the accumulation of $\mathrm{Fe}, \mathrm{Mn}, \mathrm{Cd}$ and $\mathrm{Zn}$ occurred down to $10 \mathrm{~cm}$ and that of $\mathrm{Cu}, \mathrm{Pb}$ and $\mathrm{Cr}$ down to $8 \mathrm{~cm}$. Whereas the column which was supplied with distilled water was considered as a control and showed a very low mobilization of heavy metals.

The addition of the nutritive materials to the incubated sediments was one of the factors responsible for the activation of the autochthonous bacteria and the acidification of the sediments hence the solubilization of the heavy metals but also the composition of the studied sediments (clay sediments with a high contamination of carbonate) was responsible for the readsorption of the solubilized heavy metals to the sediments [40].

These results showed that the leaching of the metals from the sediments in the incubated columns simulates the fate of metals in the real scenery and it gives rise to results on the distribution of the elements that confirmed that the polluted sediments themselves have a good capacity to immobilize the soluble fraction of the elements. However, under conditions of abundant rain and floods of the river in winter, the sediments and the soil in the studied region (with a high level of pollution) do pose a high risk with respect to the contamination of underground waters if one considers the total amount of metals potentially leachable below $25 \mathrm{~cm}$ of sediments and soil and what is of great importance is that the acidification of the sediments due to bacterial activity can promote the leaching of certain elements.
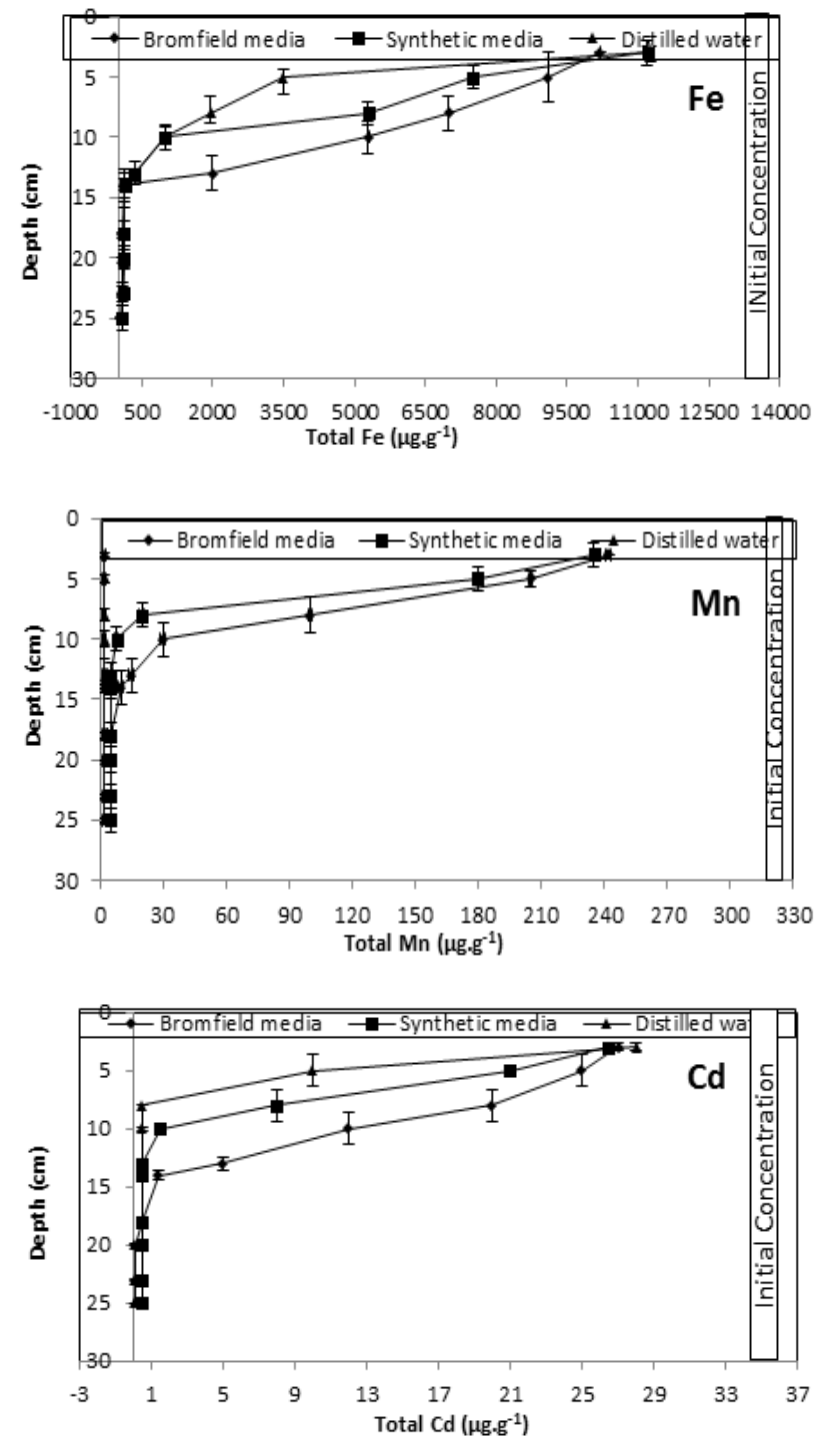

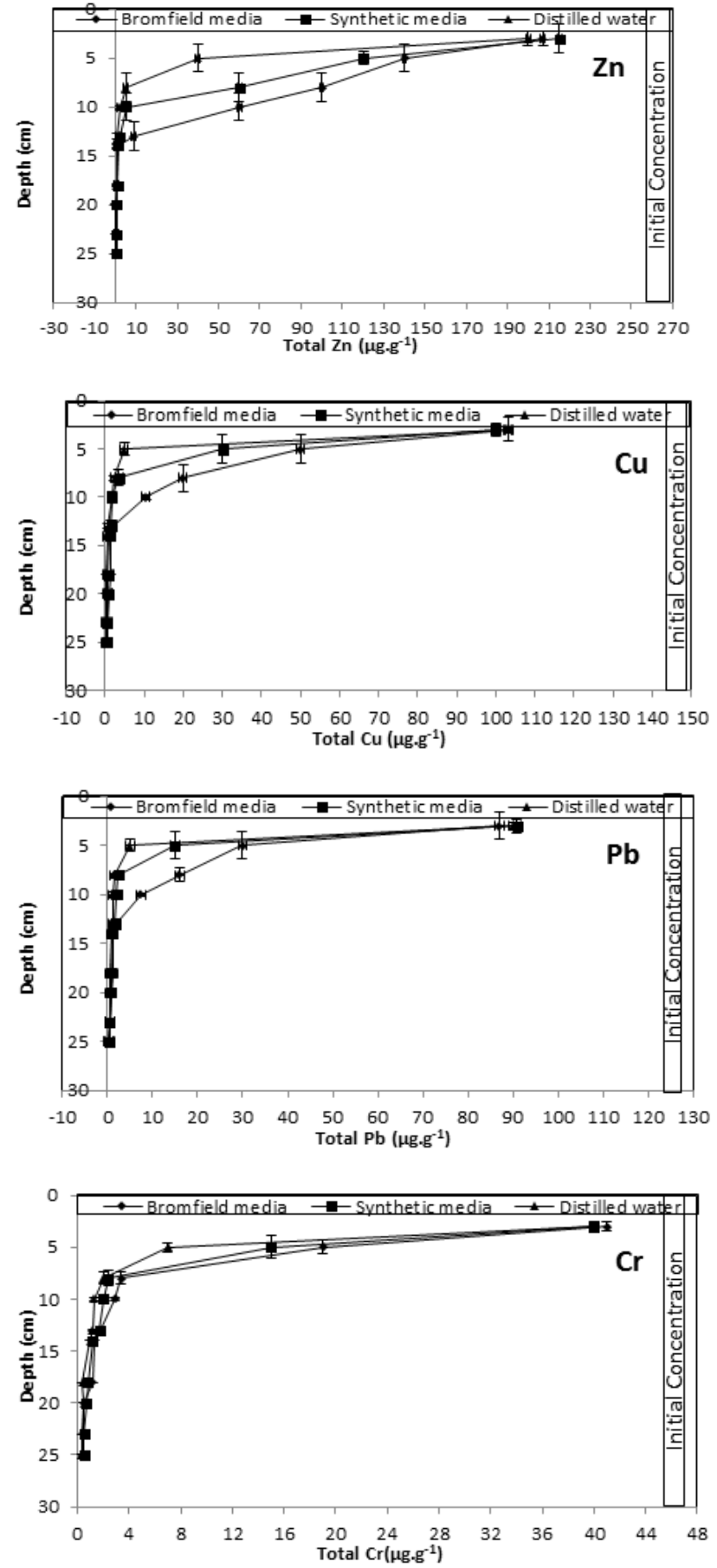

Figure 4. Vertical distribution profile of metals in the incubated sediments with the different media.

This latter phenomenon could mainly affect elements that are adsorbed as exchange cations by soil and sediment colloids [46], such as $\mathrm{Cd}$ and $\mathrm{Zn}$, which could change from being moderately mobile in soils with $\mathrm{pH}$ of 6 to highly mobile if the sediments were to reach $\mathrm{pH}$ values below this. The decrease in $\mathrm{pH}$ would also affect $\mathrm{Cu}$ and $\mathrm{Pb}$ [14], which would change from being almost immobile to being moderately mobile.

At the end of the experiment and in order to detect the effect of the heavy metals on the soil microflora which were effective on the solubilization of the heavy metals through the production of the organic acids and the decrease of the $\mathrm{pH}$, bacterial counting was done on the sediments taken from the top and the bottom of the columns at the end of the incubation and compared with the initial diagnosis of the sediment microflora.

Results obtained (Table 3 ) confirmed a certain toxicity of the metals toward the anaerobic endogenous soil microflora (initial diagnosis of the sediments showed the presence of $1.2 * 107 \mathrm{CFU} / \mathrm{g}$ of dry sediments). This counting putted in evidence a good repartition of this microflora along the whole column where no significant difference was shown between the results obtained at the top and the bottom of the same column but the difference was shown before and after incubation of the sediments in the columns where a slight decrease in the bacterial density was shown at the end of the incubation, this decrease may be due to consumption of the nutritive materials in the column which were important for their survival and which may begin to consume the 2ry metabolites produced by them. A sharp decrease in the bacterial density was shown in the column which was supplied with distilled water and without the addition of external nutritive materials, where the presence of small concentrations of nutritive materials in the sediments was not sufficient to keep the bacterial density the same.

Table 3. Bacterial counting at the top and the bottom of the columns at the end of the experiment (in CFU).

\begin{tabular}{ll|l|l}
\hline Bacteria (CFU) & $\begin{array}{l}\text { Column with } \\
\text { Bromfield } \\
\text { media }\end{array}$ & $\begin{array}{l}\text { Column with } \\
\text { the Synthetic } \\
\text { media }\end{array}$ & $\begin{array}{l}\text { Column with } \\
\text { the distilled } \\
\text { water }\end{array}$ \\
\hline $\begin{array}{l}\text { Top of the column } \\
\begin{array}{l}\text { Bottom of the } \\
\text { column }\end{array}\end{array}$ & $2.1 * 106$ & $7.4 * 104$ & $2.5 * 103$ \\
\hline
\end{tabular}

These results were confirmed with the molecular technique using the PCR-DGGE, which aim was to detect and to compare the temporal variation of the bacterial diversity in

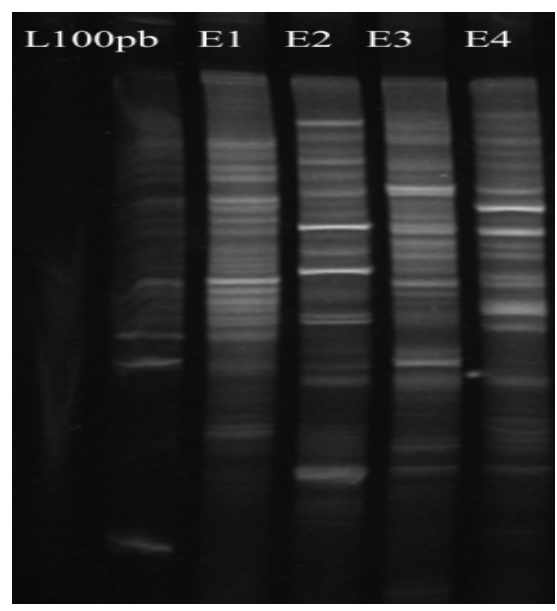

Figure 5. DGGE profiles of PCR-amplified 16S rDNA gene from sediment samples before and after their incubation with the different media (E1: sediment sample before incubation; E2: sediment sample after incubation with Bromfield media; E3: sediment sample after incubation with the synthetic media; E4: sediment sample after incubation with distilled water). 
the different sediments before and after their incubation to see whether the incubated conditions were responsible for the changes in the microbial community.

Comparison of DGGE profiles shows that the structures of the bacterial communities in the different incubated sediments differ before and after their incubation and also differ from one another before and after their incubation (Figure 5) where many bands appear in common in the different sediments but these bands were present as intense bands in some sediments while as faint bands in other sediments indicating that the incubating conditions were favorable for the growth and the intensification of certain groups of bacteria but also these conditions were responsible for the partial disappearance of many other groups which appeared as faint bands.

\section{Conclusion}

Carefully interpreted column leaching experiments provide valuable information on labile metal pools, metal sorption affinity, the coupling of simultaneous processes such as cation exchanges, carbonate dissolution, readsorption and endogenous bacterial activity as well as on the importance of slow reaction kinetics in metals leaching. Such information should prove useful for the calibration of transport models used to assess the risk of metal leaching at contaminated sites. Results obtained reflect the leaching of the metals at the contaminated sites and showed that their leaching was very low in the calcareous sediment column and varied between metals. This leaching has been accelerated by the stimulation of the endogenous bacterial activity by the addition of complex nutritive media and which mimics the wastewaters released continuously in the river in the studied region.

$\mathrm{Cr}$ and $\mathrm{Pb}$ showed the greatest difficulty in leaching into the sediment solution, $\mathrm{Fe}, \mathrm{Mn}$ and $\mathrm{Cd}$ reached the greatest concentration in the leachates and $\mathrm{Cu}$ and $\mathrm{Zn}$ an intermediate behavior. According to this leaching sequence, it seems clear that in sediments and soils carbonated by sorption sites, competition between metals is a major risk for groundwater contamination and raises the probability of absorption by plants especially of the most mobile and toxic metals. This contamination was detected in both the groundwater and plants cultivated and consumed in the region (results not published here) and which threaten the region by the increase in the level of the diseases affecting the people living there. The analysis of the distribution profile of the heavy metals in the incubated sediment columns has showed that the metals have leached from the sediments during incubation in a homogenous manner, but since the system is continuous, the arrival of the leachate rich in solubilized metals has led to the re-adsorption of the metals to the sediments. This repartition depend on the height of the sediment where it was shown that the re-adsorption was maximum at the surface of the column sediments $(0-10 \mathrm{~cm})$ and decreases with depth $(10-25 \mathrm{~cm})$ convincing the important role of clay and carbonated sediments in the adsorption of heavy metals hence decreasing their leaching to the underground waters and open the door to the thinking about the application of remediation techniques on the studied site to immobilize the heavy metals such as those techniques based on the addition to the polluted soils of limestone, clay minerals, zeolites, hydroxyapatite, Fe oxides and organic materials which are currently being tested in soils from zone with a view to selecting the most appropriate technique.

\section{References}

[1] Jurdi, M. (1992). 'A National Study on the Quality of Potable Water in Lebanon', in Proceedings of the National Workshop of the Status of Water in Lebanon, Beirut, Lebanon: 145-173 (in Arabic).

[2] Khair, K.; Aker, N.; Haddad, F.; Jurdi, M. and Hachach, A. (1994). 'The environmental impacts of humans on ground water in Lebanon', Water, Air Soil Pollut. 78: 37-49.

[3] Jurdi, M. (1998). 'Follow up National Environmental Surveillance, 1996', Unicef Publications, Beirut. (in Arabic).

[4] Sene, K.J.; Marsh, T.J and Hachache, A. (1999), 'An assessment of the difficulties in quantifying the surface water resources of Lebanon', Hydro. Sci. J. 44(1): 79-96.

[5] Low, K.S. and Lee, C.K. (1991). Cadmium uptake by the Moss, Calymperes delessertii, Besch, Biores. Technol. 38: 1-6.

[6] Grolimund, D.; Borkovec, M.; Barmettler, K. and Sticher, H. (1996). Colloid-facilitated transport of strongly sorbing contaminants in natural porous media: A laboratory column study. Environ. Sci.Technol. 30: 3118-3123.

[7] Kretzschmar, R., and H. Sticher. (1997). Transport of humiccoated iron oxide colloids in a sandy soil: Influence of $\mathrm{Ca} 2+$ and trace metals. Environ. Sci. Technol. 31:3497-3504.

[8] Temminghoff, E.J.M.; van der Zee, S.E.A.T.M. and de Haan, F.A.M. (1997). Copper mobility in a copper contaminated sandy soil as affected by $\mathrm{pH}$, solid and dissolved organic matter. Environ. Sci. Technol. 31:1109-1115.

[9] Kedziorek, M.A.M.; Dupuy, A.; Bourg, A.C.M. and Compère, F. (1998). Leaching of $\mathrm{Cd}$ and $\mathrm{Pb}$ from a polluted soil during the percolation of EDTA: Laboratory column experiments modeled with a non-equilibrium solubilization step. Environ. Sci. Technol. 32:1609- 1614.

[10] Ross, S.M. (1994). Retention, Transformation and Mobility of Toxic Metals in Soils. In: Toxic Metal in Soil-Plant Systems, pp. 63-152. (Ross, S.M., Ed.) West Sussex, England, John Wiley \& Sons.

[11] Alloway, B.J. (1995). Soil processes and the behavior of heavy metals. In: Heavy Metals in Soils, pp. 11-35. (Alloway, B.J., Ed.) Glasgow, Chapman and Hall.

[12] Andras, P.; Lichy, A.; Kusnierova, M.; Krizani, I; Ladomersky, J.; Ruskova, J. and Hroncova, E. (2009). Heavy metal distribution at dump-field Lubietova - Podlipa and possibilities of clay fraction natural sorbent utilisation. Acta Montanistica Slovaca, 14(2): 127-142.

[13] Stevenson, F.J. (1994). Humus Chemistry. Genesis, Composition and Reactions. Wiley-Intersc. Publ., New-York. 
[14] McBride, M.B. (1994). Environmental Chemistry of Soils, New York, Oxford University Press.

[15] Amusan, A.A. and I.F. Adeniyi, I.F. (2005). Genesis, classification and heavy metal retention potential of soils in mangrove forest, Niger Delta, Nigeria. J. Hum. Ecol., 17(4): 255-261.

[16] Onweremadu, E.U. (2008). Physico - chemical characterization of a farmland affected by wastewater in relation to heavy metals. J. Zhejiang Univ. Sci. A., 9(3): 366372 .

[17] Motos, G.D. and Arruda, M.A.Z. (2003). Vermicompost as natural adsorbent for removing metal ions from laboratory effluents, Process Biochem. 39: 81-88.

[18] Bousserrhine, N. (1995). "Etude de paramètres de la réduction bactérienne du fer et application à la defferification de minéraux industriels", Université Henry Poincaré, Nancy I : 331.

[19] Lovley, D.R. (1991). Dissimilatory Fe (III) and Mn (IV) reduction. Microbiological reviews; 55: 259-287.

[20] Tormo, M.A. and Izco, J.M. (2004). “Alternative reversedphase high-performance liquid chromatography method to analyse organic acids in dairy products", Journal of Chromatography A, 1033(2): 305-310.

[21] Muyzer, G.; de Waal, E.C. et Uitterlinden, A.G. (1993). Profiling of complex microbial populations by denaturing gradient gel electrophoresis analysis of polymerase chain reaction amplified genes coding for 16S rRNA. Appl. Environ. Microbiol; 59: 695-700.

[22] Charlatchka, R. and Cambier, P. (2000). "Influence of Reducing Conditions on Solubility of Trace Metals in Contaminated Soils", Water, Air, \& Soil Pollution, 118: 143168.

[23] Dassonville, F.; Godon, J.J.; Renault, P.; Richaume, A. and Cambier, P. (2004). "Microbial dynamics in an anaerobic soil slurry amended with glucose, and their dependence on geochemical processes", Soil Biology and Biochemistry, 36: 1417-1430.

[24] Fakih, M.; Alphonse, V.; Garnier-Zarli, E. and Bousserrhine, N. (2010). "Mercury mobilization in ferralitic soils under reductive conditions", Science of the Total Environment.

[25] Lovley, D.R. and Phillips, E.JP. (1988). "Novel mode of microbial energy metabolism: organic carbon oxidation coupled to dissimilatory reduction of iron or manganese". Applied and Environmental Microbiology, 54: 1472-1480.

[26] Rajot, J.-L. (1992). Dissolution des oxydes de fer (hématite et goethite) d'un sol ferralitique des Llanos de Colombie par des bactéries ferri-réductrices. Université de Nancy; 185.

[27] Sims, J.L. and Patrick, W.H. (1978). "The distribution of micronutrient cations in soil under conditions of varying redox potential and $\mathrm{pH}$, Soil Science Society of America Journal, 42: $258-262$.

[28] Calmano, W.; Hong, J. and Förstner, U. (1993). "Binding and mobilization of heavy metals in contaminated sediments affected by $\mathrm{pH}$ and redox potential", Water Science and Technology, 28.
[29] Chuan, M.C.; Shu, G.Y. and Liu, J.C. (1996). "Solubility of heavy metals in a contaminated soil: Effects of redox potential and $\mathrm{pH}$ ", Water, Air, and Soil Pollution, 90: 543-556.

[30] Stumm, W.; Morgan, J.J. (1996). "Aquatic chemistry, chemical equilibria and rates in natural waters", Trace Metals: Cycling, Regulation, and Biological Role. 3rd ed. John Wiley and Sons, Inc, USA.

[31] Chen, S.Y. and Lin, J.G. (2001). "Bioleaching of heavy metals from sediments: significance of $\mathrm{pH}$ ", Chemosphere, 44: 10931102.

[32] Gundersen, P. and Steinnes, E. (2003). "Influence of pH and TOC concentration on $\mathrm{Cu}, \mathrm{Zn}, \mathrm{Cd}$ and $\mathrm{Al}$ speciation in rivers", Water Research, 37: 307-318.

[33] Qureshi, S.; Richards, B.K.; Hay, A.G.; Tsai, C.C.; Mcbride, M.B.; Baveye, P. and Steenhuis, T.S. (2003). "Effect of microbial activity on trace element release from sewage sludge", Environmental Science \& Technology; 37: 33613366 .

[34] Yang, J.Y.; Yang, X.E.; He, Z.L.; Li, T.Q.; Shentu, J.L. and Stoffela, P.J. (2006). "Effects of $\mathrm{pH}$, organic acids, and inorganic ions on lead dissolution from soils", Environmental Pollution, 143: 9-15.

[35] Linde, M.; Öborn, I. \& Gustafsson, J.P. (2007). Effects of changed soil conditions on the mobility of trace metals in moderately contaminated urban soils. Water, Air and Soil Pollution, 183: 69-83.

[36] Korte, N.E.; Scopp, J.; Fuller, W.H.; Niebla, E.E. and Alesii, B.A. (1976). Trace element movement in soils: Influence of soil physical and chemical properties. Soil Sci. 122: 350-359.

[37] Sánchez-Camazano, M. and Sánchez-Martín, M.J. (1993). Mobility of cadmium as influenced by soil properties, studied by soil thin layer chromatography. J. Chromatograph.: 357362.

[38] Sánchez-Camazano, M.; Sánchez-Martín, M.J. and Lorenzo, L.F. (1994). Content and distribution of cadmium in natural soils as influenced by soil properties. Sci. Total Environ. 156: 183-190.

[39] Hargital, L. (1995). Some aspects of the mobility and distribution of toxic heavy metals contaminants in soil profiles and river sediments. Int. J. Environ. Anal. Chem. 59: 317-325.

[40] Sánchez-Camazano, M.; Sánchez-Martín, M.J. and Lorenzo, L.F. (1998). Significance of soil properties for content and distribution of cadmium and lead in natural calcareous soils. Sci. Total Environ. 218: 217-226.

[41] Tyler, L.D. and McBride, M.B. (1982). Mobility and extractability of cadmium, copper, nickel, and zinc in inorganic and mineral soil columns. Soil Sci. 134: 189-205.

[42] Hickey, M.G. and Kittrick, J.A. (1984). Chemical partitioning of cadmium, copper, nickel and zinc in soils and sediments containing high levels of heavy metals. J. Environ. Qual. 13: 373-376.

[43] Missana, T.; Garcia-Guttierez, U. and Alonso, U. (2008). Sorption of strontium onto illite/smectite mixed clays. Phys. Chem. Earth, 33(Supl. 1): 156-162. 
[44] Amer, M.W.; Khalili F.I. and Awwad, A.M. (2010). Adsorption of lead, zinc and cadmium ions on polyphosphatemodified kaolinite clay. J. Environ. Chem. Ecotoxicol., 2(1): 001-008.

[45] Camobreco, V.J.; Richards, B.K.; Steenhuis, T.S.; Peverly, J.H. and McBride, M.B. (1996). Movement of heavy metals through undisturbed and homogenized soil columns. Soil Sci. 161: 740-750.
[46] Kabata-Pendias, A. et Pendias, H. (2001). Trace elements in soils and plants. 3rd CRC Press, BocaRaton, London, NewYork, Washington, DC: 403. 